\title{
Comparison and Analysis on the Process of Master Curve Determination for Hot Mix Asphalt
}

\author{
Kwan-Ho Lee 1* $^{*}$ \\ ${ }^{1}$ Dept. of Civil Engineering, Kongju National University \\ 아스팔트 혼합물의 마스터곡선 작성 방법의 비교 및 분석 \\ 이관호 $1^{*}$ \\ ${ }^{1}$ 국립공주대학교 건설환경공학부
}

\begin{abstract}
The dynamic modulus of hot mix asphalt is one of the important indicators to evaluate the durability and performance of asphalt pavement. In resent, the dynamic modulus is suggested by a key property of asphalt pavement design and analysis in AASHTO 2002 Design Guide and Korean Pavement Research Project(KPRP). Master curve from laboratory test results should be needed for pavement design and analysis. The process to get the master curve is standardized. But, there are some setup and testing error at low temperature $\left(-10^{\circ} \mathrm{C}\right)$ and high temperature $\left(55^{\circ} \mathrm{C}\right)$. In this paper, a simplified process which is used 3 testing temperatures $(5,21,40)$ is adopted to get the master curve. Comparison was carried out for standard process and simplified process. The suggested process can be used to get the master curve of asphalt pavement, even though some difference was shown at high temperature.
\end{abstract}

요 약 아스팔트 혼합물의 동탄성계수는 포장체의 내구성 및 공용성을 평가하는데 매우 중요한 지표이다. 최근 미 국의 AASHTO 2002 설계법 및 한국형 포장설계법에서도 아스팔트 포장체의 가장 중요한 물성중 하나를 동탄성계수 로 정의하였고, 이를 아스팔트 포장의 설계 및 해석에 적극 이용하고 있다. 동탄성계수를 설계에 이용하기 위해서는 마스터곡선을 작성하여야 한다. 마스터곡선은 각각의 아스팔트 혼합물을 이용하여 평가된 동탄성계수 값을 이용하여 결정한다. 마스터곡선을 결정하는 방법은 표준화되어 있으나, 저온영역(-10도)에서는 시험장비 계측장비의 결로로 인 한 측정오차 및 고온영역(55도)에서는 아스팔트 바인더의 유체화 및 실험기기 세팅상의 문제들이 발생하여 측정 결 과값에 큰 영향을 준다. 따라서, 이러한 온도대역의 자료를 제외한, 5 도, 21 도 및 40 도에서 측정된 결과값을 이용하 여 마스터곡선을 작성 및 분석하였고, 이를 기존의 표준방법으로 결정한 마스터곡선과 비교하였다. 본 연구에서 제안 된 방법을 이용하여 결정된 마스터곡선은 고온영역에서 차이가 있기는 하지만, 충분히 사용가능한 것으로 판단되었다.

Key Words : Dynamic modulus, master curve, Gyratory compactor, Pavement design, Hot mix asphalt

\section{Introduction}

NCHRP Project I -37A is producing the new 2002 Design Guide for New \& Rehabilitated Pavements. The guide is based on mechanistic principles and requires a modulus, analogous to $\mathrm{E}$ for steel, to compute stress and strains in hot-mix asphalt (HMA) pavements. In 1999, the NCHRP Panel for Project 1-37A selected $E^{*}$ for this purpose. The selection was based on a paper authored by
Witczak(1999) which compared $E^{*}$ to an Indirect Diametral Test (MR). Both of these test procedures have been in use by the research community for over 30 years.

The current state-of-practice in Superpave hot mix asphalt design is to rely almost solely on the volumetric composition of asphalt mixtures. The AASHTO 2002 design guide aims to introduce more rigorous measures of performance into hot mix asphalt mixtures and pavement design procedures. Research by numerous groups has 
shown that the complex modulus can be used to characterize temperature dependent mixture stiffness and viscosity characteristics over time. Similarly, the complex modulus has been shown to be a potential measure of the accumulation of damage, including cracking in materials. Current nation-wide efforts have been focusing on obtaining the complex modulus of mixtures with the cyclic triaxial test, or with the Superpave Simple Shear Test. The triaxial test works well for the characterization of laboratory-prepared mixtures[1].

The AASHTO provisional test standard TP62-03 is performed at temperatures of $-10,4.4,21.1,37.8$ and 54.4 ${ }^{0} \mathrm{C}$. Frequencies of $25,10,5,1,0.5$ and $0.1 \mathrm{~Hz}$ are specified for loading the sample at each temperature. The recommended protocol is a stress-controlled version of the complex modulus test in which the sinusoidal (haversine) cyclic load applied to the specimen is adjusted so that the specimen is subjected to axial strains between 50 and 150 microstrain $(\mu \varepsilon)$. This constraint is in place to guarantee that testing is being performed within the linear viscoelastic zone. According to the current test protocol, the stress level should be selected from a certain range set for each test temperature[2][3].

To get the dynamic complex modulus, 5 different testing temperatures and loading frequencies are used. Two test temperatures, such as $-10{ }^{\circ} \mathrm{C}$ and $54.4{ }^{\circ} \mathrm{C}$, which can simulate at low temperature in winter and high temperature in summer in pavement, are not significant to make master curve.

In this paper, a simplified test procedure of dynamic complex modulus will be suggested to get the master curve of hot-mix asphalt. The master curve, from standard test protocol and simplified test procedure(at 5, 21, and $40^{\circ} \mathrm{C}$ ) will be compared.

\section{Dynamic Modulus}

\subsection{Theoretical Basis}

Briefly, $E^{*}$ is the modulus of a visco-elastic material. The dynamic (complex) modulus of a visco-elastic test is a response developed under sinusoidal loading conditions. It is a true complex number as it contains both a real and imaginary component of the modulus and is normally identified by $\mathrm{E}^{*}$ (or $\mathrm{G}^{*}$ ). In visco-elastic theory, the absolute value of the complex modulus $\left|\mathrm{E}^{*}\right|$, by definition, is the Dynamic Modulus. In the general literature, however, the term, "ynamic Modulus" is often used to denote any type of modulus that has been determined under "on-static"load conditions.

For linear visco-elastic materials such as HMA mixtures, the stress-strain relationship under a continuous sinusoidal loading is defined by its complex dynamic modulus ( $\left.\mathrm{E}^{*}\right)$ This is a complex number that relates stress to strain for linear visco-elastic materials subjected to continuously applied sinusoidal loading in the frequency domain. The complex modulus is defined as the ratio of the amplitude of the sinusoidal stress at any given time, $\mathrm{t}$, and the angular load frequency, $\omega, \delta=\delta \sin (\omega \mathrm{t})$ and the amplitude of the sinusoidal strain $\varepsilon=\varepsilon \operatorname{cosin}(\omega t-\varnothing)$, at the same time and frequency, that results in a steady state response (Figure 1):

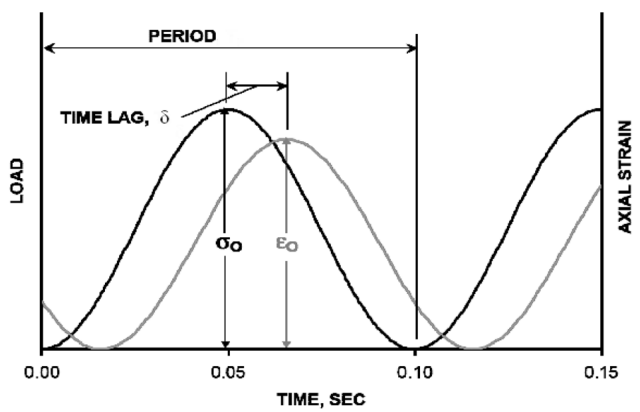

[Fig. 1] Dynamic Modulus Test

$$
E^{*}=\frac{\delta}{\epsilon}=\frac{\delta_{o} e^{i w t}}{\epsilon_{o} e^{i(w t-\Phi)}}=\frac{\delta_{o} \sin w t}{\epsilon_{o} \sin (w t-\Phi)}
$$

Where,

$$
\begin{aligned}
& \delta_{0}=\text { peak (maximum) stress } \\
& \varepsilon_{0}=\text { peak (maximum) strain } \\
& \varnothing=\text { phase angle, degrees } \\
& \omega=\text { angular velocity } \\
& \mathrm{t}=\text { time, seconds } \\
& \mathrm{i}=\text { imaginary component of the complex modulus }
\end{aligned}
$$

Mathematically, the dynamic modulus is defined as the absolute value of the

complex modulus, or:

$$
\left|E^{*}\right|=\frac{\delta_{o}}{\epsilon_{o}}
$$




\subsection{Master Curve}

Master curves are constructed using the principle of time-temperature superposition. The data at various temperatures should be shifted with respect to log of time until the curves merge into a single smooth function [4][5]. The resulting master curve of the modulus, as a function of time, formed in this manner describes the time dependency of the material. The amount of shift required at each temperature required to form the master curve describes the temperature dependency of the material. In general, the master modulus curve can be mathematically modeled by a sigmoidal function described as:

$$
\log \left(\left|E^{*}\right|\right)=\delta+\frac{\alpha}{1+\exp ^{\beta-\gamma \log \left(t_{r}\right)}}
$$

Where,

$\mathrm{t}_{\mathrm{r}}=$ time of loading at reference temperature

$\delta=$ minimum value of $\mathrm{E}^{*}$

$\delta+a=$ maximum value of $E^{*}$

$\beta, \gamma=$ parameters describing the shape of the sigmoidal function.

$a=$ variable which is a function of gradation

The shift factor can be shown in the following form:

$a(T)=\frac{t}{t_{r}} \mathrm{a}$

Where,

$\mathrm{a}(\mathrm{T})=$ shift factor, as a function of temperature

$\mathrm{t}=$ time of loading during test

$\mathrm{t}_{\mathrm{r}}=$ time of loading at reference temperature (usually $\left.70^{\circ} \mathrm{C}\right)$

$\mathrm{T}=$ temperature of loading cycle

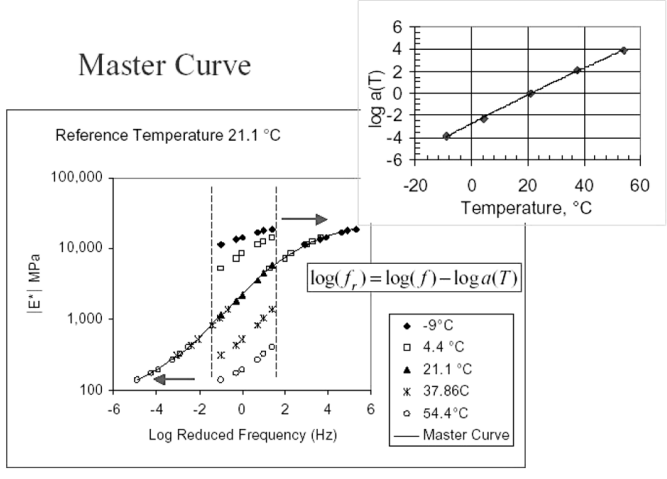

[Fig. 2] Master Curve of HMA

\section{Experimental Investigation}

\subsection{Materials and Test Specimen}

The focus of this research was to evaluate the complex modulus of several asphalt mixtures from Korea's granite and to suggest the simplified testing method. Four different mixtures were selected at the beginning of the project and tested. The gradation of the mixtures are shown in Table 1 . PG 58-22 of asphalt binder is adopted. The detailed properties of each mixture are shown in Table 2.

[Table 1] Gradation of Hot-Mix Asphalt

\begin{tabular}{|c|c|c|c|c|}
\hline $\begin{array}{l}\text { Sieve } \\
(\mathrm{mm})\end{array}$ & $\mathbf{A}$ & $\mathbf{B}$ & $\mathbf{C}$ & $\mathbf{D}$ \\
\hline 25 & 100 & 100 & 100 & 100 \\
\hline 19 & 100 & 97.5 & 87 & 100 \\
\hline 12.5 & 97.5 & 82.5 & 76 & 95 \\
\hline 9.5 & 82.5 & 68.75 & 65 & 61.25 \\
\hline 4.75 & 67.5 & 55 & 49 & 27.5 \\
\hline 2.36 & 51 & 39.5 & 37 & 20 \\
\hline 1.18 & 39 & 31.25 & 34 & 18 \\
\hline 0.6 & 27 & 23 & 17 & 16 \\
\hline 0.3 & 18.5 & 15.5 & 14 & 13.5 \\
\hline 0.15 & 11 & 10 & 9 & 11.75 \\
\hline 0.075 & 7 & 5 & 4 & 10 \\
\hline
\end{tabular}
A : dense graded $13 \mathrm{~mm}$ for surface
B : dense graded $19 \mathrm{~mm}$ for surface
$\mathrm{C}$ : dense graded $25 \mathrm{~mm}$ for base
D : SMA $13 \mathrm{~mm}$ for surface

[Table 2] Volumetric Properties of HMA

\begin{tabular}{|c|c|c|c|c|}
\hline Properties & A & B & C & D \\
\hline $\mathrm{G}_{\mathrm{mm}}$ & 2.482 & 2.495 & 2.501 & 2.51 \\
\hline $\mathrm{G}_{\mathrm{sb}}$ & 2.647 & 2.647 & 2.647 & 2.647 \\
\hline $\mathrm{V}_{\mathrm{a}}(\%)$ & 4.182 & 3.694 & 3.865 & 3.666 \\
\hline $\mathrm{OAC}(\%)$ & 5.2 & 5.1 & 4.3 & 5.7 \\
\hline
\end{tabular}

Cylindrical specimens $100-\mathrm{mm}$ by $150-\mathrm{mm}$ were prepared according to NCHRP Project 9-29. Cylindrical specimens $150-\mathrm{mm}$ by $170-\mathrm{mm}$ specimens were compacted in the laboratory using the gyratory compactor. They were then cored to a $100-\mathrm{mm}$ diameter and saw cut to a final height of $150 \mathrm{~mm}$. The air voids were measured on the finished test specimens. All the test specimen were cured at $135^{\circ} \mathrm{C}$ for 2 hours before compaction. 


\subsection{Test Equipment}

All tests were performed on an UTM-25 testing system, which includes an hydraulically-driven load-frame, rated at $25 \mathrm{kN}$, with integrally mounted hydraulic actuator, position transducer, and load cell in a -20 to $+100{ }^{\circ} \mathrm{C}$ temperature cabinet. An integrated control and data acquisition system (CDAS) provides accurate force or displacement waveform generation and control and enables automatic sequencing of test procedures. Flat, circular load platens were used to apply the load to the specimen. Latex paper was used to reduce friction at the end plates. The vertical deformation measurements were obtained using two LVDT. One average strain measurement was obtained from the two LVDT.

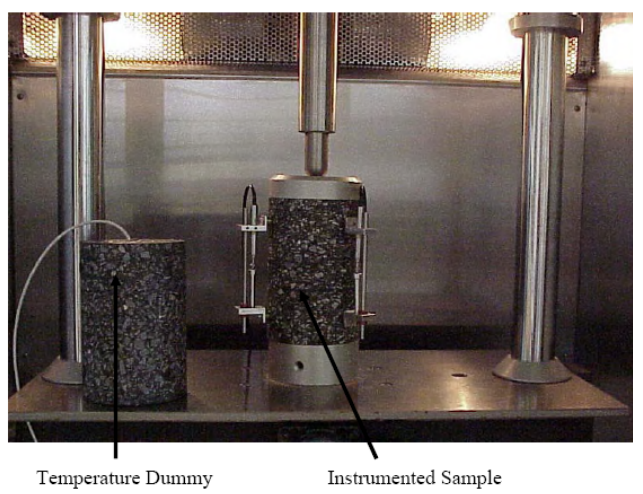

[Fig. 3] Testing Setup

\subsection{Test Procedures}

All the testing procedure was based on NCHRP 9-29 proposed standard A1: "Dynamic Modulus of Asphalt Concrete Mixtures and Master Curves". The recommended procedure involves performing tests at several different temperatures and loading frequencies. For the comparison of dynamic complex modulus and master curve, two different temperature sets, which shown in Table 3 , are applied.

The specimen was then placed in a freezer for overnight at $-10^{\circ} \mathrm{C}$ to ensure temperature equilibrium. The task report for the data analysis explains in detail how the raw force and displacement data is manipulated to obtain the dynamic modulus and phase angle for each specimen.

After the entire cycle of testing was complete at $-10^{\circ} \mathrm{C}$, the environmental chamber was set to the next temperature. After 2 hours conditioning, the above steps were repeated until completion of the entire sequence of temperatures and frequencies. The protocol requires 200 cycles of load conditioning, but does not state whether this is at the contact load of five percent of test load or at the $25 \mathrm{~Hz}$ test load. Table 3 to 5 of the protocol suggests dynamic stress levels for this test. If at any time during the conditioning load process the recoverable axial strain in the sample exceeds 1500 micro-strain the sample is to be discarded. The strain level range should be within 50-150 micro-strain. Experience with the $\left|\mathrm{E}^{*}\right|$ test procedure and the HMA mixes being tested is required in order to select the proper stress level that complies with the sample strain limitation.

[Table 3] Analysis Methods

\begin{tabular}{|c|c|c|}
\hline Method & $\begin{array}{c}\text { Loading } \\
\text { Frequency } \\
(\mathrm{Hz})\end{array}$ & $\begin{array}{c}\text { Temperatures } \\
\left({ }^{\circ} \mathrm{C}\right)\end{array}$ \\
\cline { 1 - 1 } Standard & $\begin{array}{c}0.1,0.5,1, \\
5,10,25\end{array}$ & $-10,5,21,40,55$ \\
\cline { 1 - 1 } Simplified & $5,21,40$ \\
\hline
\end{tabular}

[Table 4] Cycles for Test Sequence

\begin{tabular}{|c|c|}
\hline Frequency, Hz & Number of Cycles \\
\hline Preconditioning (25) & 206 \\
25 & 106 \\
10 & 106 \\
1 & 56 \\
0.1 & 6 \\
0.05 & 6 \\
\hline
\end{tabular}

[Table 5] Typical Dynamic Stress Levels

\begin{tabular}{|c|c|}
\hline Temperature, ${ }^{\circ} \mathrm{C}$ & Range, $\mathbf{k P a}$ \\
\hline-10 & $1400-2800$ \\
5 & $700-1400$ \\
21 & $350-700$ \\
40 & $140-250$ \\
55 & $35-70$ \\
\hline
\end{tabular}

\subsection{Test Results and Analysis}

In general, it is not easy to keep the low temperature at $-10^{\circ} \mathrm{C}$ and to make a testing noise due to freezing of measuring devices. Also, there is some problems to test at high temperature $\left(55^{\circ} \mathrm{C}\right)$, such as the meltdown of asphalt 
binder and the unstable setup of testing device. Therefore, the measured testing data at $-10^{\circ} \mathrm{C}$ and $55^{\circ} \mathrm{C}$ have some more noise. This induces the error to make the master curve for each hot mix asphalt.

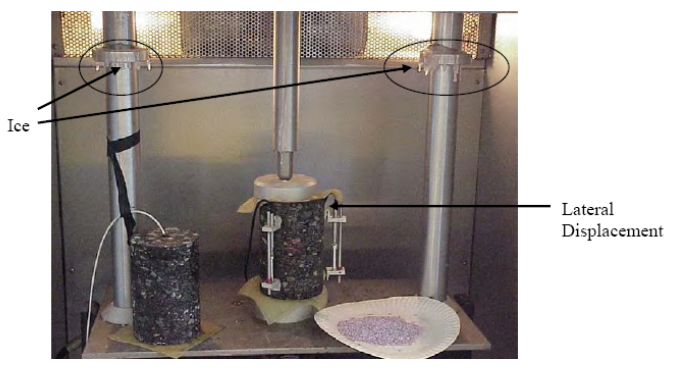

[Fig. 4] Test Set-up at $-10^{\circ} \mathrm{C}$

In this study, the simplified method, with 3 different testing temperatures for $5^{\circ} \mathrm{C}, 21^{\circ} \mathrm{C}$ and $40^{\circ} \mathrm{C}$ is suggested to get the master curve. Test results for dynamic modulus of each mixtures are shown in Table 6 . The range of measured dynamic modulus are between $446 \mathrm{MPa}$ and 45,353 MPa. The master curves for standard method and simplified method are shown in Figure 4. As shown in Figure 4, there is not big difference of master curve for standard and simplified method, at the range of log reduced tiem, -4 to 6 .

At low testing temperature, the difference of analysis method for master curve can be ignored, but at high temperature, the master curve for both methods is not similar.

For the purpose of asphalt pavement design, the log reduced time would be used between -5 and 5 , which can be simulate the vehicle speed, loading duration on pavement and temperature.

[Table 5] Dynamic Modulus (MPa)

\begin{tabular}{|c|c|c|c|c|c|}
\hline $\begin{array}{c}\text { Tempera } \\
\text { ture } \\
\left({ }^{\circ} \mathrm{C}\right)\end{array}$ & $\begin{array}{c}\text { Frequency } \\
(\mathrm{Hz})\end{array}$ & $\begin{array}{c}13 \mathrm{~mm} \\
\text { HMA }\end{array}$ & $\begin{array}{c}19 \mathrm{~mm} \\
\text { HMA }\end{array}$ & $\begin{array}{c}25 \mathrm{~mm} \\
\text { HMA }\end{array}$ & $\begin{array}{c}\text { SMA } \\
\text { HMA }\end{array}$ \\
\hline \multirow{5}{*}{-10} & 0.1 & 29206 & 29667 & 24206 & 25061 \\
\cline { 2 - 6 } & 0.5 & 30623 & 33482 & 25623 & 29498 \\
\cline { 2 - 6 } & 1 & 32083 & 35372 & 26416 & 31741 \\
\cline { 2 - 6 } & 5 & 36443 & 42405 & 27441 & 34888 \\
\cline { 2 - 6 } & 10 & 39065 & 43914 & 29065 & 37017 \\
\hline \multirow{4}{*}{5} & 0.1 & 15517 & 21374 & 15161 & 14546 \\
\cline { 2 - 6 } & 0.5 & 18199 & 24625 & 17079 & 18618 \\
\cline { 2 - 6 } & 1 & 21161 & 27546 & 20161 & 19968 \\
\hline
\end{tabular}

\begin{tabular}{|c|c|c|c|c|c|}
\hline \multirow{5}{*}{} & 10 & 25607 & 34273 & 25940 & 28176 \\
\cline { 2 - 6 } & 25 & 27286 & 36829 & 27296 & 32948 \\
\hline \multirow{5}{*}{21} & 0.1 & 4952 & 5812 & 4997 & 2710 \\
\cline { 2 - 6 } & 0.5 & 6465 & 9567 & 6131 & 4475 \\
\cline { 2 - 6 } & 1 & 8208 & 11189 & 7541 & 5275 \\
\cline { 2 - 6 } & 5 & 11631 & 15879 & 9631 & 8017 \\
\cline { 2 - 6 } & 10 & 13769 & 18048 & 12436 & 9993 \\
\hline \multirow{5}{*}{40} & 25 & 15170 & 21549 & 13503 & 11082 \\
\cline { 2 - 6 } & 0.1 & 960 & 1234 & 893 & 513 \\
\cline { 2 - 6 } & 0.5 & 1533 & 1824 & 1400 & 857 \\
\cline { 2 - 6 } & 1 & 1996 & 2557 & 1696 & 1043 \\
\cline { 2 - 6 } & 5 & 2973 & 4371 & 2840 & 1836 \\
\cline { 2 - 6 } & 10 & 4216 & 5400 & 3082 & 2766 \\
\hline \multirow{5}{*}{55} & 25 & 5141 & 7115 & 4074 & 2968 \\
\cline { 2 - 6 } & 0.1 & 580 & 534 & 547 & 446 \\
\cline { 2 - 6 } & 0.5 & 693 & 770 & 726 & 517 \\
\cline { 2 - 6 } & 1 & 804 & 875 & 838 & 627 \\
\cline { 2 - 6 } & 5 & 989 & 1267 & 1056 & 1235 \\
\cline { 2 - 6 } & 10 & 1329 & 1584 & 1363 & 1167 \\
\hline
\end{tabular}

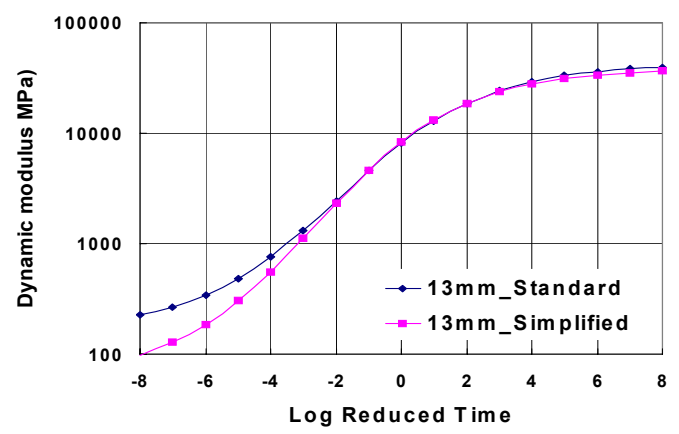

(a) $13 \mathrm{~mm}$ Dense Graded HMA

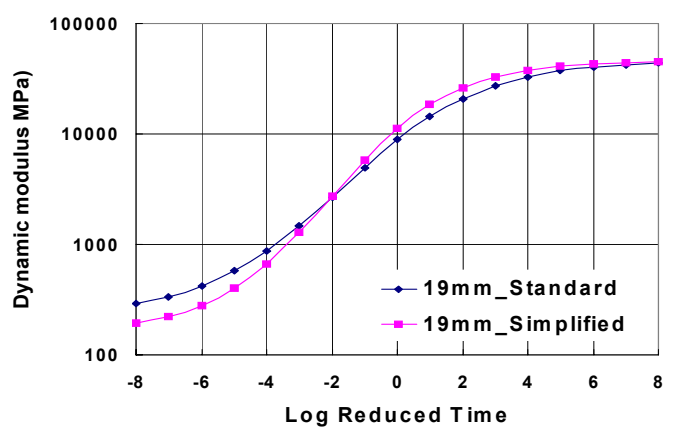

(b) $19 \mathrm{~mm}$ Dense Graded HMA 


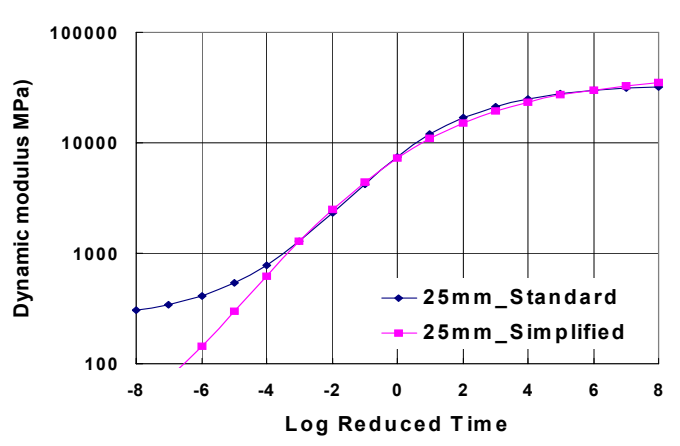

(c) $25 \mathrm{~mm}$ Dense Graded Base HMA

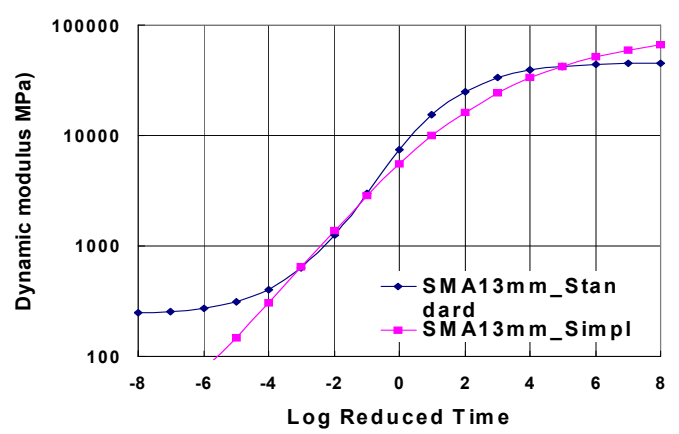

(d) SMA 13mm HMA

[Fig. 4] Comparison of Master Cuver for Standard and Simplified Anlaysis

\section{Conclusion}

- Under a constant load frequency, the dynamic modulus decreases with the increase in test temperature for the same mixture. Under a constant test temperature, the dynamic modulus increases with the increase of test frequency.

- For the wide range of temperatures for the compressive dynamic modulus test data, the use of the sigmoidal fitting function to construct the master curve seems to fit the data well because it follows the physical form of the measured data.

- There is not big difference of master curve for standard and simplified method, at the range of log reduced tiem, -4 to 6 . At low testing temperature, the difference of analysis method for master curve can be ignored, but at high temperature, the master curve for both methods is not similar. For the purpose of asphalt

pavement design, the log reduced time would be used between -5 and 5 , which can be simulate the vehicle speed, loading duration on pavement and temperature.

\section{References}

[1] Ying, H. (2010), Using X-Ray Computed Tomography to Quantify Damage of Hot-Mix Asphalt in the Dynamic Complex Modulus and Flow Number Tests, MS Thesis, Louisiana State University, pp. 121

[2\} Loulizi, A., Flintsch, G.A., Al-Qadi I.L, Mokarem, D. (2005), "Comparison between Resilient Modulus and Dynamic Modulus of Hot-Mix Asphalt as Material Properties for Flexible Pavement Design, TRB Annual Meeting

[3] Witczak, M. W. (1999), "A Comparison of the Dynamic (Complex) Modulus Test $\left(\mathrm{E}^{*}\right)$ and Indirect Diametral Test (Mr) for AC Mixtures"', Unpublished.

[4] Kim, K., Lee, J, Lee, K (2004) "A Standardized Testing Procedure and Analysis for Dynamic Modulus of Hot Mix Asphalt by Superposition of Loading and Temperature", J. of Korean Society of Civil Engineers, Vol. 24-3D, pp. 395-404

[5] Kim, K., Lee, K. (2005), "Comparison and Evaluation of Dynamic Modulus of Hot Mix Asphalt with Different Shift Factors", J. of Korean Society of Road Engineers, Vol. 7, No. 1, pp. 49-61

Kwan-Ho Lee

[Regular Member]

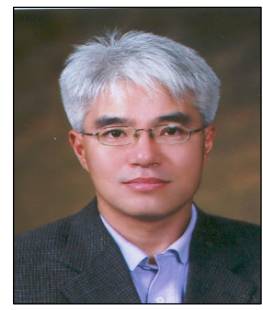

- Feb. 1991 : Dept. of Civil Eng., Korea University (MS)

- Dec. 1996 : Civil Eng., Purdue Univ., USA (Ph.D)

- Sep. $2006 \sim$ Present : Professor, Dept. of Civil Eng., Kongju National University
$<$ Research Interests $>$ Roadway Engineering 